\title{
Kombinasi Indeks Citra untuk Analisis Lahan Terbangun dan Vegetasi Perkotaan
}

\author{
Iswari Nur Hidayati ${ }^{1}$, R. Suharyadi ${ }^{2)}$ dan Projo Danoedoro ${ }^{3}$
}

Mahasiswa Program Doktor, Program Studi Geografi, Fakultas Geografi UGM, Yogyakarta, Indonesia ${ }^{1}$ Fakultas Geografi, Universitas Gadjah Mada Yogyakarta, Indonesia ${ }^{2,3}$ Email Koresponden: iswari@ugm.ac.id

Diterima: Januari 2018 /Disetujui: Februari 2018 / Publikasi online: Maret 2018 (๑) 2018 Fakultas Geografi UGM dan Ikatan Geograf Indonesia (IGI)

\begin{abstract}
Lahan terbangun di perkotaan dan area vegetasi menjadi hal yang sangat menarik untuk dikaji. Apalagi dinamika penggunaan lahan di perkotaan yang sangat cepat berubah. Berbagai metode dikembangkan untuk ekstraksi lahan terbangun di perkotaan, mulai dari klasifikasi multispektral, object based approach, hingga penelitian berbasis indeks. Normalized Difference Built-up Index (NDBI) menjadi salah satu indeks pioner untuk ekstraksi lahan terbangun perkotaan dengan menggunakan saluran SWIR. Pengembangan indeks lahan terbangun ini masih perlu dikembangan untuk citra yang tidak mempunyai panjang gelombang Short Wave Infra Red (SWIR). Tujuan penelitian ini adalah merumuskan kombinasi saluran terbaik dalam ekstraksi lahan terbangun dan area vegetasi serta menghitung kepadatan bangunan dan kerapatan vegetasi berbasis indeks. Penelitian ini menggunakan Citra Worldview-2 yang diperoleh dari Digital Globe Foundation untuk ekstraksi lahan terbangun dan kerapatan vegetasi. Normalized difference index digunakan sebagai formula dalam pembuatan indeks. Pemanfaatan semua saluran spektral dalam citra Worldview- 2 digunakan untuk ekstraksi lahan terbangun dan kepadatan bangunan di perkotaan dengan PCA sebagai metode untuk penggabungan delapan saluran dalam Worldview-2. Saluran NIR 1 dan NIR 2 yang digabungkan dengan Saluran Merah menjadi pilihan untuk ekstraksi vegetasi. Proses trial dan error mewarnai pemilihan kombinasi saluran yang digunakan dan treshold yang digunakan untuk analisis biner dalam membedakan lahan terbangun dan non lahan terbangun serta area vegetasi dan area non vegetasi. Pemanfaatan unique identification (UID) digunakan untuk pembuatan grid berbasis raster dalam perhitungan kepadatan bangunan dan kerapatan vegetasi. Hasil penelitian menunjukkan bahwa indeks yang dibangun dengan PC2 dan NIR 1 serta PC2 dan NIR 2 mempunyai akurasi tinggi yaitu 94,43\% untuk bangunan dan kombinasi indeks dari NIR1_Red mempunyai akurasi optimal yaitu 99,51\% dan NIR2_Red mempunyai akurasi 92,87 untuk ekstraksi data vegetasi.
\end{abstract}

Kata kunci : kombinasi indeks citra, analisis grid, kepadatan bangunan, kerapatan vegetasi

\begin{abstract}
Urban phenomenon becomes a very interesting thing to be studied. The urban land use, land conversion, urban green space, are rapidly changing. Various methods were developed for urban built-up data extraction, such as multispectral classification, object-based approach, and index-based research. Normalized Difference Built-up Index (NDBI) became one of pioneer indices for urban-built urban land extraction using Short Wave Infra Red (SWIR) band. The development of this built-up index is still required for images that do not have SWIR wavelengths. The study objectives were to select the best methods for built-up land and vegetation extraction and to calculate building density and index-based vegetation density. Worldview-2 image obtained from Digital Globe Foundation tested for built-up land data extracting and vegetation density analyzing. Normalized difference index formula is applied for combining and setting built-up land and vegetation indexes. Merger of Worldview-2 spectral imagery were using PCA method for extracting built-up land and calculating building density. Combining eight bands into eight new images that have different information from original images was done by PCA method. NIR 1, NIR2, and Red bands are the perfect choice for vegetation extraction because near infrared characteristics have high reflections on vegetation. Selection of band combinations and selection of threshold values through trial and error processes to perceive the best index combinations and reasonable threshold values. Binary analysis is particularly useful for separating the built-up and non-built-up areas as well as vegetation and non-vegetation. The Unique identification (UID) technique used in estimating built-up and vegetation density from precisely classified images provided better and accurate assessment of built-up and vegetation density. The results show that the built-up index involving PC2_NIR 1 and PC2_NIR 2 for the urban built land research achieved an optimal accuracy of $94,43 \%$. The best accuracy for vegetation data extraction was obtained from the combined NIR1_Red index with 99,51\% and NIR2_Red values with an overall accuracy of 92,87\%.
\end{abstract}

Key words: index image combination, grid analysis, building density, vegetation density

\section{PENDAHULUAN}

Kota akan selalu tumbuh dan berkembang sejalan dengan kehidupan sosial dan ekonomi di dalamnya. Richnau et al., (2012) menyatakan bahwa perkembangan kota dipengaruhi oleh tiga hal yaitu ekologi, teknologi, dan organisasi sosial. Perkembangan kota juga tidak akan pernah lepas dari sejarah pertumbuhan kota, kondisi masa kini, dan pertumbuhan kota yang akan datang. Perkembangan dan bentuk kota merupakan satu kesatuan yang tidak dapat dipisahkan dan ditinjau 
dengan pola morfologi kota. Fenomena perkembangan kota akan mencakup perkembangan elemen kota secara detail, elemen bentuk kota serta perkembangan peraturan kota (Schindler \& Caruso, 2014). Kota juga menawarkan keanekaragaman fasilitas, kemudahan transportasi, sarana, dan prasarana yang sangat memadai sehingga mempengaruhi penduduk untuk melakukan perpindahan dari desa ke kota. Dalam arti lain, urbanisasi merupakan perubahan permukiman pedesaan menjadi permukiman perkotaan yang secara langsung berpengaruh kepada perubahan lingkungan perkotaan.

Data penginderaan jauh mempunyai peranan yang sangat penting untuk ekstraksi penggunaan lahan perkotaan. Esktraksi data terkait lahan perkotaan secara visual dari segi kualitas permukiman (Farizki \& Anurogo, 2017) juga menjadi topik bahasan yang sangat menarik. Penelitian terkait dengan temperature humidity index yang menggambarkan tentang kenyamanan kota (Caroline \& Hidayati, 2016) juga menjadi varian dalam kajian perkotaan. Ekstraksi digital data penggunaan lahan di perkotaan khususnya lahan terbangun perkotaan sudah dimulai dari klasifikasi supervised menggunakan neural network analysis (Abiden et al., 2010; Bahadur \& Murayama, 2012; Maithani, 2009), object based analysis (Blaschke, 2010), dan knowledge-based approach analysis (Forestier et al., 2012; Hidayati, 2010; Millward-Hopkins et al., 2011) untuk meningkatkan klasifikasi penggunaan lahan perkotaan. Ekstraksi NDBI di mulai oleh penelitian (Zha et al., 2003) dengan memberikan informasi terkait ekstraksi otomatis lahan terbangun menggunakan citra Landsat TM walaupun masih ada kekuarangan belum bisa membedakan dengan lahan terbuka perkotaan. Penggunaan citra landsat dengan resolusi menengah untuk ekstraksi NDBI telah banyak dilakukan oleh peneliti sebelumnya (Chen et al., 2006; Deng \& Wu, 2012; Guo et al., 2015; Hidayati et al., 2017). Akan tetapi penggunaan pada citra Landsat memanfaatkan panjang gelombang SWIR untuk ekstraksi lahan terbangun, sementara di citra resolusi tinggi seperti Worldview tidak mempunyai panjang gelombang SWIR, sehingga perlu dikaji lebih lanjut tentang peranan masing-masing saluran untuk ekstraksi lahan terbangun (Kumar et al., 2012). Permasalahan di perkotaan tidak hanya berkutat pada ekstraksi lahan terbangun, akan tetapi ekstraksi lahan vegetasi yang semakin lama semakin berkurang. Normalized difference vegetation index menjadi alternatif untuk ektraksi vegetasi di daerah perkotaan menggunakan NIR band dan saluran Merah (Purwanto, 2015). Tujuan Penelitian ini memanfaatkan citra resolusi tinggi (worldview-2) untuk ekstraksi lahan terbangun dan lahan vegetasi berbasis indeks disertai dengan kepadatan vegetasi dan kepadatan bangunan yang dihasilkan dari kombinasi band yang tersedia pada citra Worldview-2. Untuk mengembangkan hasil agar lebih optimal, maka normalized difference index digunakan untuk melakukan kombinasi berbagai band. Principle Component Analysis (PCA) juga digunakan untuk menggabungkan semua band untuk meningkatkan akurasi penelitian. Perhitungan kepadatan bangunan dan kepadatan vegetasi berdasarkan analisis unique identification (UID) berdasarkan grid/raster yang dibentuk.

\section{METODE PENELITIAN}

Area penelitian pada sebagian wilayah Kecamatan Kraton, Kota Yogyakarta (Gambar 1). Data Citra yang digunakan adalah Citra Worldview-2 yang diperoleh dari Digital Globe Foundation, dengan tanggal perekaman 16 September 2015 (Gambar 2) yang mempunyai delapan saluran multispektral dan satu saluran pankromatik dengan cloud cover 0,010 (Tabel 1). Variasi resolusi spektral dalam citra Worldview-2 memberikan kontribusi dalam penelitian ini untuk membentuk skema dan pemilihan gabungan indeks terbaik dari delapan saluran yang dimiliki oleh citra.

Tabel 1. Resolusi Spektral dan Spasial Citra Worldview 3 dibandingkan citra satelit generasi sebelumnya

\begin{tabular}{|c|c|c|c|}
\hline Nama Band & Worldview 1 & Worldview 2 & Worldview 3 \\
\hline Pankromatik & $400-900 \mathrm{~nm}$ & $450-800 \mathrm{~nm}$ & $450-800 \mathrm{~nm}$ \\
\hline Resolusi Spasial & $0,46 \mathrm{~m}$ & $0,46 \mathrm{~m}$ & $0,31 \mathrm{~m}$ \\
\hline Coastal Blue & & $400-450 \mathrm{~nm}$ & $400-450 \mathrm{~nm}$ \\
\hline Biru & & $450-510 \mathrm{~nm}$ & $450-510 \mathrm{~nm}$ \\
\hline Hijau & & $510-580 \mathrm{~nm}$ & $510-580 \mathrm{~nm}$ \\
\hline Kuning & & $585-625 \mathrm{~nm}$ & $585-625 \mathrm{~nm}$ \\
\hline Merah & & $630-690 \mathrm{~nm}$ & $630-690 \mathrm{~nm}$ \\
\hline Red Edge & & $705-745 \mathrm{~nm}$ & $705-745 \mathrm{~nm}$ \\
\hline NIR-1 & & $770-895 \mathrm{~nm}$ & $770-895 \mathrm{~nm}$ \\
\hline NIR-2 & & $860-1040 \mathrm{~nm}$ & $860-1040 \mathrm{~nm}$ \\
\hline Resolusi Spasial & & $1,84 \mathrm{~m}$ & $1,24 \mathrm{~m}$ \\
\hline
\end{tabular}


SWIR-2

SWIR-4

$1710-1750 \mathrm{~nm}$

SWIR-5

$2145-2185 \mathrm{~nm}$

SWIR-6

$2185-2225 \mathrm{~nm}$

SWIR-7

$2235-2285 \mathrm{~nm}$

SWIR-8

$2295-2365 \mathrm{~nm}$

Resolusi Spasial $3,7 \mathrm{~m}$ Sumber: Digitalglobe, 2014

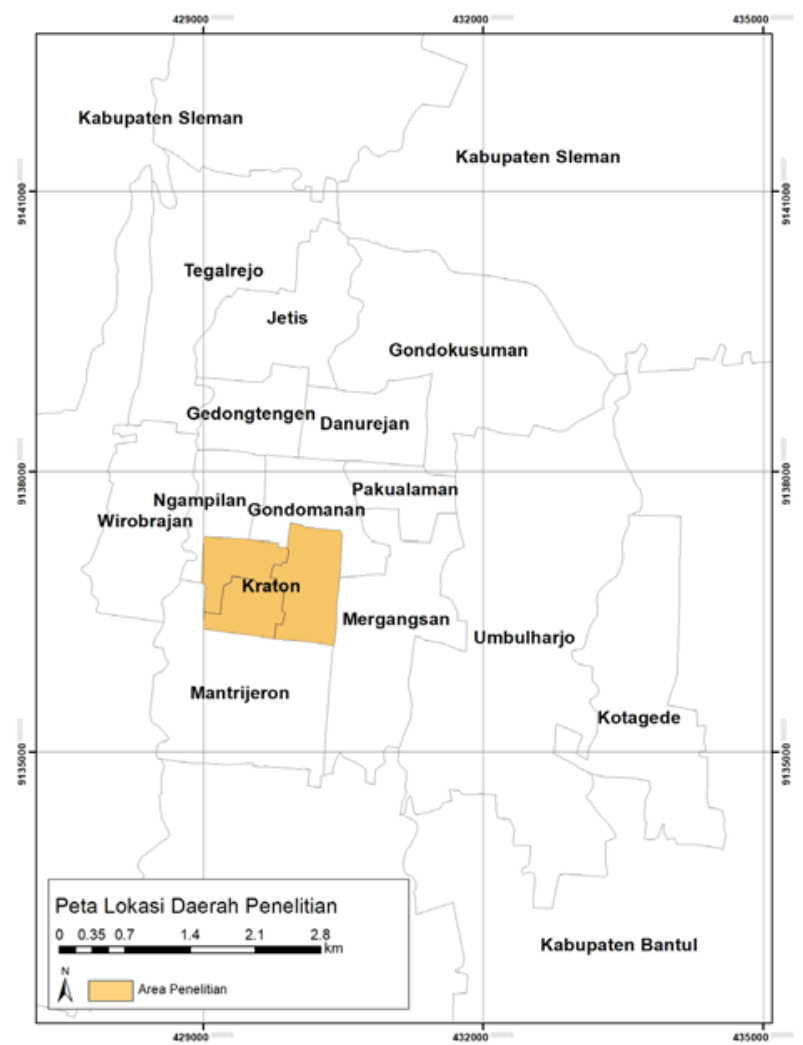

Gambar 1. Peta Lokasi Penelitian

\section{Ekstraksi Lahan Terbangun}

NDBI atau indeks lahan terbangun merupakan suatu algoritma untuk menunjukkan kerapatan lahan terbangun/bare soil (Guo et al., 2015). NDBI sangat sensitif terhadap lahan terbangun atau lahan terbuka. Algoritma ini dipilih karena merupakan transformasi yang paling sering digunakan untuk mengkaji indeks lahan terbangun. Ektraksi NDBI pada citra Landsat menggunakan saluran SWIR, akan tetapi pada citra Worldview-2 tidak memiliki saluran SWIR, sehingga perlu dilakukan penelitian tentang peranan masingmasing saluran terhadap lahan terbangun perkotaan. Pembuatan indeks untuk lahan terbangun melibatkan semua panjang gelombang pada citra Worldview-2.
Proses penggabungan semua band pada citra Worldview-2 menggunakan PCA (Principle Component Analysis) untuk meringkas informasi dari 8 (delapan) band murni menjadi delapan band luaran yang masingmasing tidak berkorelasi (Nichol \& Wong, 2009). Proses awal yang dilakukan dalam penelitian ini adalah mempertimbangkan semua hasil transformasi PC. Dari hasil pengamatan diperoleh bahwa kombinasi dari NIR1, NIR2, dan Red Edge dengan metode Normalized Difference Index mempunyai kenampakan visual dan digital lebih baik jika dibandingkan dengan kombinasi yang lain. Seleksi tahap kedua dalam proses pemilihan indeks menentukan bahwa kombinasi band PC2 dengan NIR1, PC2 dengan NIR2, PC4 dengan NIR 1, dan PC3 


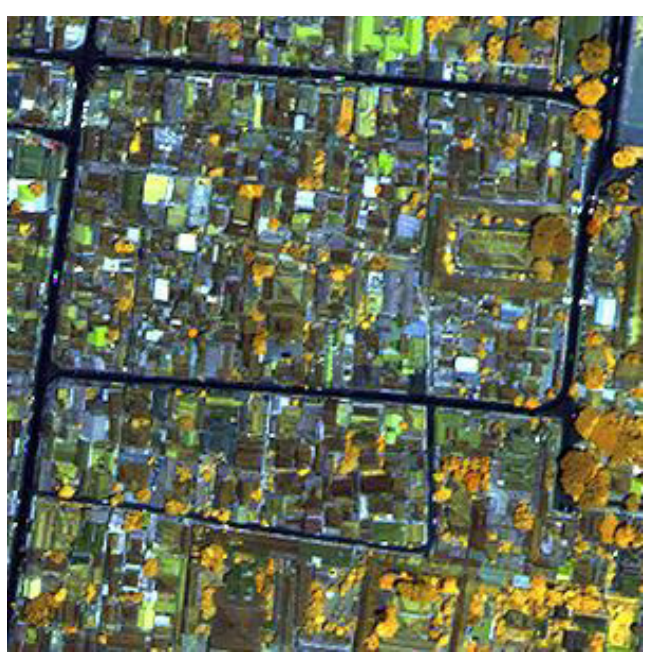

Komposit 763

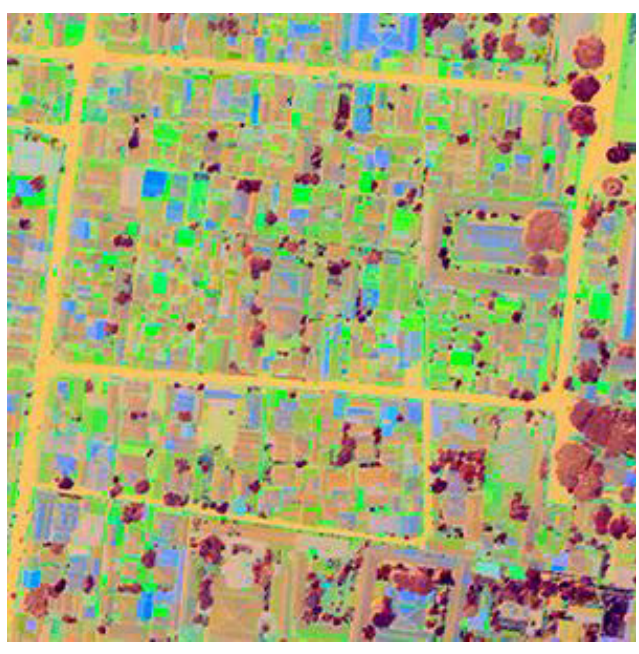

Komposit PC 123

Gambar 2. Hasil Komposit Citra Worldview-2 untuk Kepadatan Bangunan

(Sumber: Digital Globe, 2016)

Red Edge digunakan untuk analisis ekstraksi lahan terbangun perkotaan. Dari keempat saluran terpilih kemudian dibuat Normalized Difference Index seperti formula di bawah ini:

$\mathrm{PCnew}=(\mathrm{PC} 2-\mathrm{NIR} 1) /(\mathrm{PC} 2+\mathrm{NIR} 1)$

Keempat saluran tersebut mempunyai kenampakan visual yang baik untuk lahan terbangun. Gambar 2 merupakan hasil komposit PC1,2,3 yang secara visual yang dapat membedakan kenampakan jalan terhadap kenampakan lahan terbangun. Bandingkan dengan Gambar 3.

\section{Ekstraksi Vegetasi}

Indeks Vegetasi merupakan suatu algoritma yang diterapkan pada citra multisaluran untuk menonjolkan aspek kerapatan vegetasi ataupun aspek yang berkaitan dengan biomass, Leaf Area Index, konsentrasi klorofil, jumlah tajuk dan lain sebagainya (Hidayati, 2013; Johnson, 2014). Ekstraksi otomatis yang dilakukan melalui transformasi ini akan merepresentasikan fenomena vegetasi. Normalized Difference Vegetation Index (NDVI) merupakan kombinasi antara teknik penisbahan dengan teknik pengurangan citra. Indeks vegetasi merupakan kombinasi dari beberapa band yang dapat menghasilkan informasi terkait kerapatan vegetasi. Campbell \& Wynne (2011) menyatakan bahwa fenomena penyerapan cahaya merah oleh klorofil $(0,4$ $\mu \mathrm{m}-0,7 \mu \mathrm{m})$ pada vegetasi dan pemantulan cahaya inframerah dekat oleh jaringan mesofil $(0,7 \mu \mathrm{m}$ $1,1 \mu \mathrm{m})$ pada daun akan membuat perbedaan nilai kecerahan. Oleh karena itu, transformasi indeks vegetasi yang dipilih adalah yang melibatkan saluran merah dan saluran inframerah. Normalized Difference Index dipilih untuk melihat nilai maksimal dari satu band dan nilai minimal yang digunakan dalam band yang lain. Misalnya gabungan dari NIR1 dan Merah, maka secara matematis pantulan tertinggi pada saluran near infra merah 1 akan dikurangkan pada saluran merah.

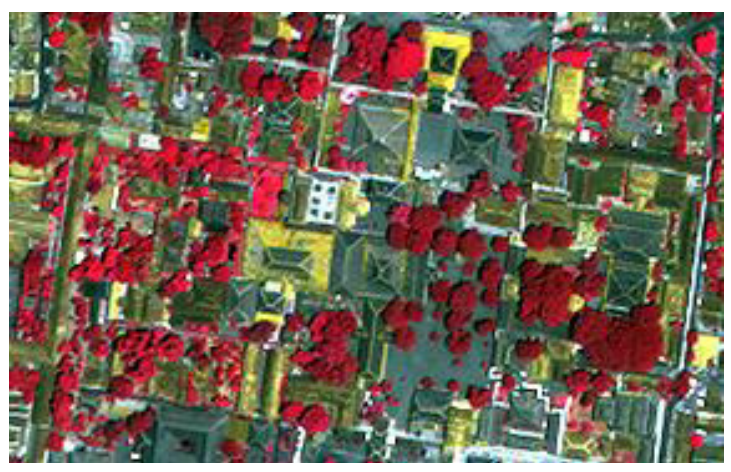

Komposit 653

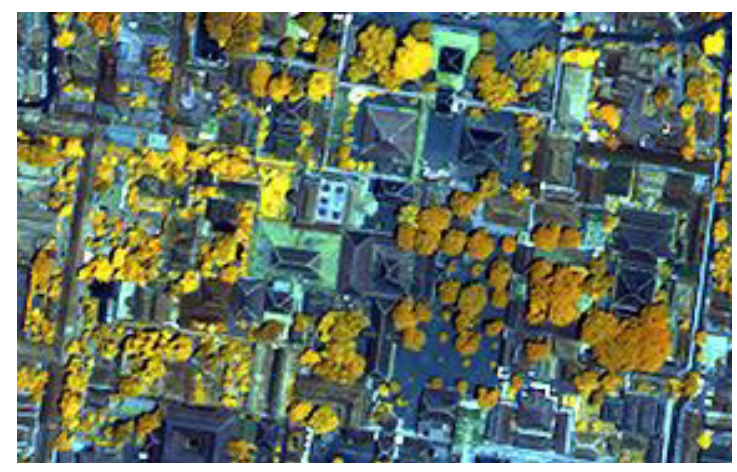

Komposit 764

Gambar 3. Tampilan False Color Composite Citra Worldview-2

(Sumber : Citra Worldview-2, 2015) 
Pembuatan indeks vegetasi menggunakan rumus normalized difference index. Dalam penelitian ini menggunakan kombinasi NIR 1 dan merah dan NIR 2 dan Merah. Hampir sama dengan pengolahan pada ekstraksi lahan terbangun, perolehan kombinasi band ini berdasarkan pada karakteristik pantulan vegetasi dan disesuaikan dengan panjang gelombang yang dimiliki oleh Citra Worldview-2. Gambar 4 merupakan hasil transformasi indeks vegetasi.

Hasil transformasi indeks dengan melibatkan NIR 1 dan Merah dan NIR 2 dan Merah, memberikan hasil yang bagus secara visual untuk ekstraksi data vegetasi. Gambar 4(b) yaitu kombinasi NIR1_RedEdge tidak digunakan analisis lebih lanjut dikarenakan secara visual dan digital tidak mempunyai distribusi nilai piksel yang baik. Nilai piksel yang dihasilkan dari transformasi indeks NIR 1 dan Merah mempunyai nilai minimal -0,4 dan nilai maksimal 0,7. Hasil indeks kombinasi NIR 2 dan Merah menghasilkan nilai minimal $-0,7$ dan nilai maksimal 0,5. Hasil nilai transformasi indeks kemudian dilihat nilai threshold untuk batas vegetasi, artinya mencari batas nilai indeks yang digunakan untuk daerah bervegetasi dan tidak bervegetasi. Pemilihan nilai threshold dilakukan secara terus menerus dengan trial and error hingga mendapatkan nilai yang optimal dan producer accuracy yang baik. Citra indeks yang dihasilkan kemudian diubah menjadi citra biner yang membedakan antara vegetasi dan non vegetasi.

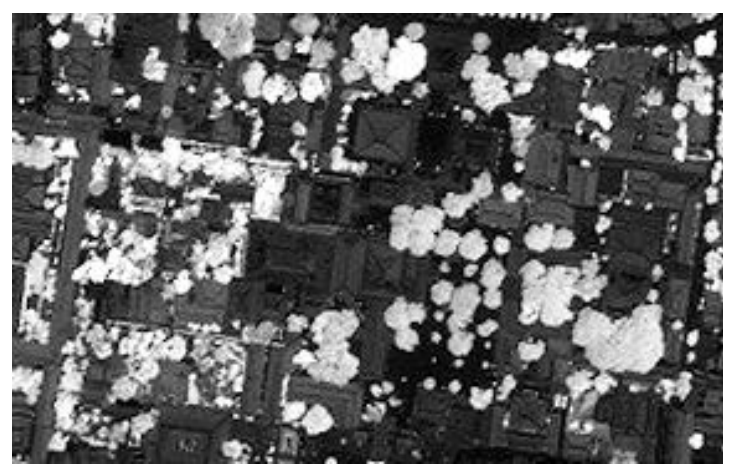

NIR 1 dan Merah

\section{HASIL DAN PEMBAHASAN Kepadatan Lahan Terbangun}

Hasil ekstraksi lahan terbangun dari proses PCA yang digunakan untuk penelitian selanjutnya adalah kombinasi PC2-NIR 1, PC2-NIR 2, PC3-Red Edge, dan PC4-NIR1. Kombinasi ini digunakan setelah mencari kombinasi yang terbaik jika dibandingkan dengan kombinasi PC dengan NIR1, NIR2, dan Red Edge (Gambar 5). Dari keempat kombinasi ini dapat membedakan penggunaan lahan terbangun, jalan, dan lahan terbuka. Pembuatan kepadatan bangunan berbasis indeks ini menggunakan keempat indeks yang telah terbentuk selanjutnya. Pengambilan batas threshold untuk bangunan dan non bangunan menggunakan analisis biner. Pembuatan grid $50 \mathrm{~m} \mathrm{x}$ $50 \mathrm{~m}$ selanjutnya digunakan untuk analisis kepadatan bangunan menggunakan metode unique identification (UID) berdasarkan data raster yang sudah terbentuk dan menghasilkan 64 grid analisis untuk kepadatan bangunan. Kepadatan bangunan dihitung berdasarkan masing-masing grid yang selanjutnya dikelompokkan menjadi kelas kepadatan bangunan yaitu kepadatan sangat tinggi (>60\%), kepadatan tinggi (40\%-60\%), kepadatan sedang (10\%-40\%), kepadatan rendah (0\%$10 \%)$, dan tidak ada bangunan.

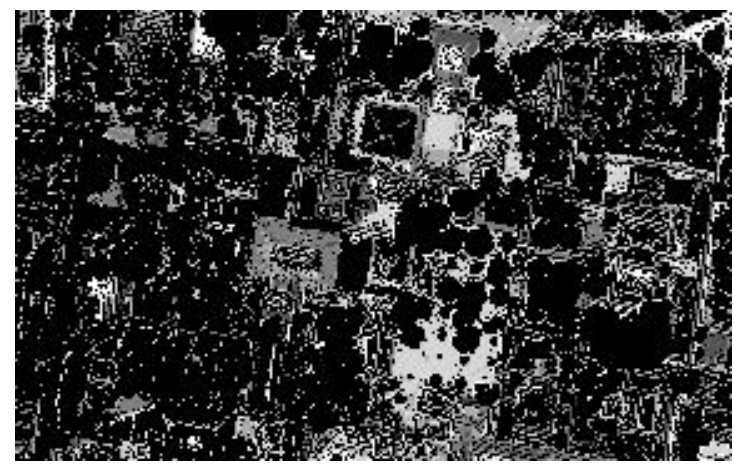

NIR 1 dan Red Edge

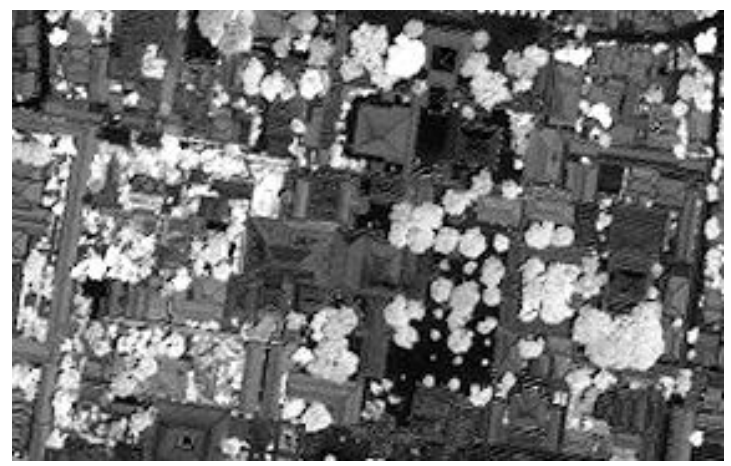

NIR 2 dan Merah

Gambar 4. Hasil Transformasi NDVI (Sumber:Analisis, 2017) 


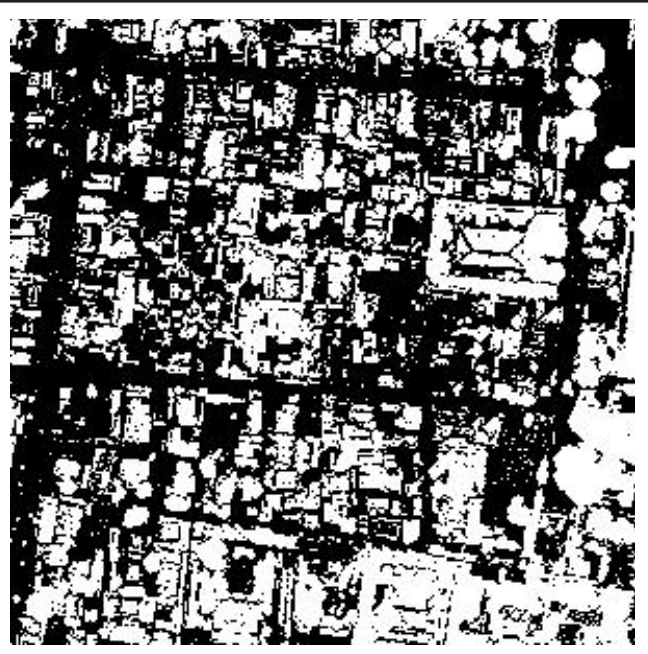

PC2 - NIR 1

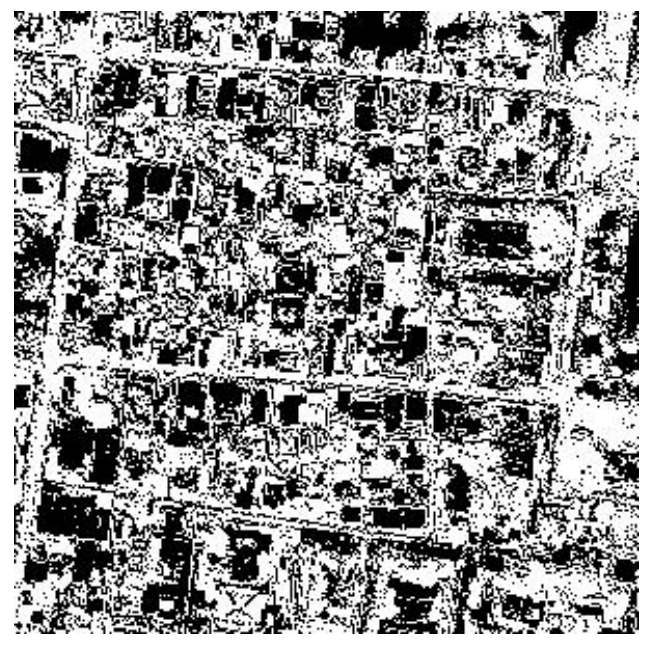

PC3 - RedEdge

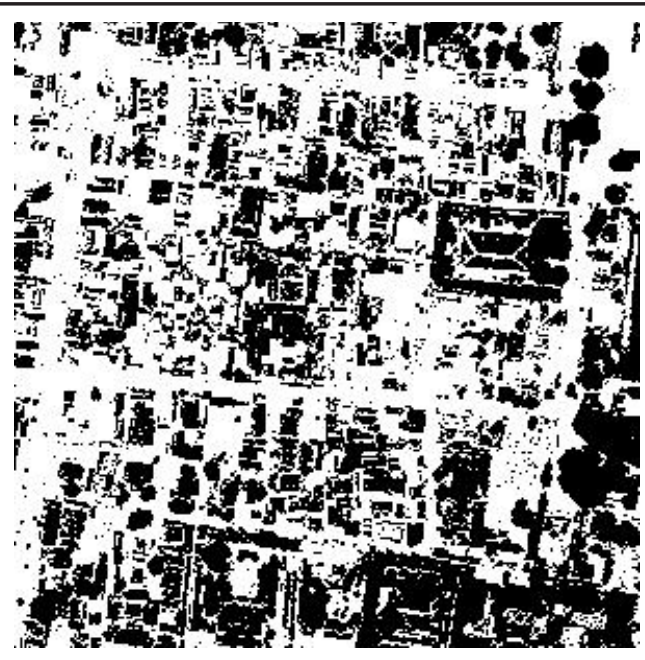

PC2 - NIR 2

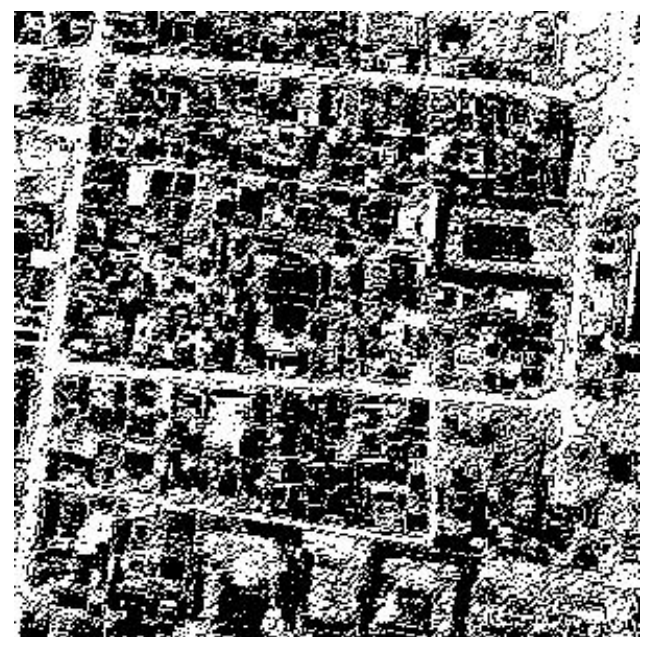

PC4 - NIR 1

Gambar 5. Hasil Transformasi Index untuk Kepadatan Bangunan (Sumber:Analisis, 2017)

Tabel 2. Kepadatan Banguan berbasis Indeks pada Area Penelitian

\begin{tabular}{ccccccccc}
\hline $\begin{array}{c}\text { Kepadatan } \\
\text { Bangunan }\end{array}$ & \multicolumn{2}{c}{ PC2 dan NIR1 } & \multicolumn{2}{c}{ PC3 dan Red edge } & \multicolumn{2}{c}{ PC4 dan NIR1 } & \multicolumn{2}{c}{ PC2 dan NIR2 } \\
Luas (m2) & $\begin{array}{c}\text { Persentase } \\
(\%)\end{array}$ & Luas (m2) & $\begin{array}{c}\text { Persentase } \\
(\%)\end{array}$ & Luas (m2) & $\begin{array}{c}\text { Persentase } \\
(\%)\end{array}$ & Luas (m2) & $\begin{array}{c}\text { Persentase } \\
(\%)\end{array}$ \\
\hline Sangat Tinggi & $10.829,76$ & 8,36 & $17.218,56$ & 13,29 & $3.382,40$ & 25,76 & $10.829,76$ & 8,36 \\
Tinggi & $23.119,52$ & 17,84 & $52.454,40$ & 40,47 & $35.240,96$ & 27,19 & $23.119,52$ & 17,84 \\
Sedang & $20.991,04$ & 16,20 & $1.463,04$ & 1,13 & $3.325,76$ & 2,57 & $20.991,04$ & 16,20 \\
Rendah & 23,04 & 0,02 & 0,00 & 0,00 & 36,48 & 0,03 & 23,04 & 0,02 \\
Total & $54.963,36$ & 42,41 & $71.136,00$ & 54,89 & $71.985,60$ & 55,54 & $54.963,36$ & 42,41 \\
\hline
\end{tabular}

Dari hasil yang diperoleh pada Tabel 2 menghasilkan bahwa hasil ekstraksi kepadatan bangunan untuk transformasi Indeks PC2_NIR1 mempunyai hasil yang sama dengan PC2_ NIR 2, begitu juga untuk luas bangunan PC3_RedEdge serta PC4_NIR1 menghasilkan nilai yang hampir sama. PC3_Red Edge menghasilkan luas wilayah klasifikasi kepadatan tinggi yang lebih tinggi jika dibandingkan dengan indeks yang lain yaitu sebesar 52454,40 m2 dan klasifikasi kepadatan rendah mempunyai nilai 0. PC4_ NIR1 menghasilkan luas area kepadatan sangat tinggi lebih rendah dibandingkan dengan yang lain. Penilaian hasil akurasi berdasarkan 200 sampel uji yang diambil secara stratified random sampling dengan bantuan 


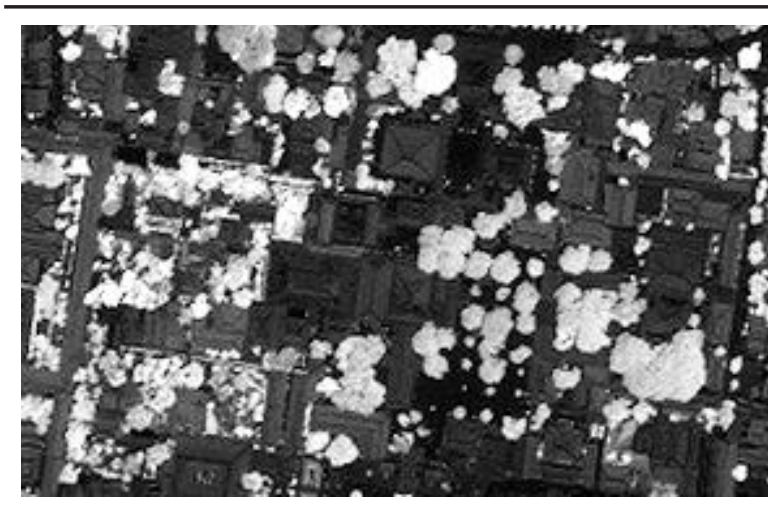

(a) Indeks Vegetasi (NIR1_Merah)

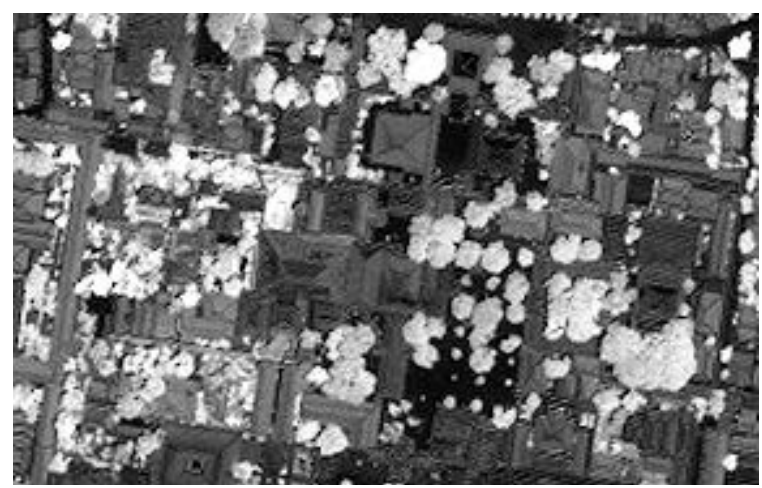

(c) Indeks Vegetasi dari NIR2_Merah

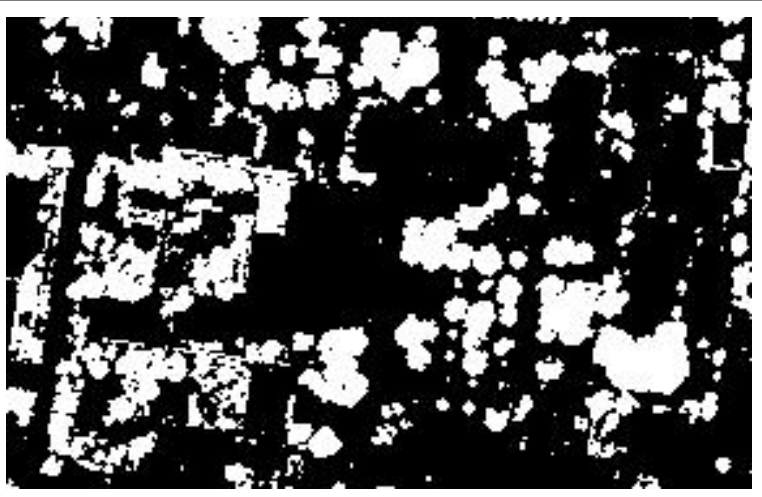

(b) Hasil Analisis Vegetasi NIR1_Merah

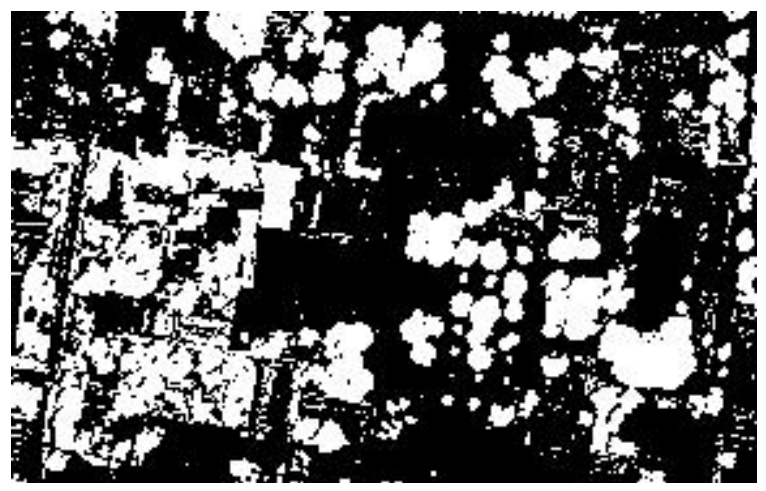

(d) Hasil Analisis Vegetasi NIR2_Merah

Gambar 6. Hasil Transformasi (a) dan (b) Hasil Analisis Vegetasi dan Non Vegetasi dengan Menentukan Nilai Treshold, hitam adalah non vegetasi dan warna putih adalah vegetasi

software image processing. Hasil akurasi indeks diperoleh gabungan PC2_NIR 1 dan PC2_NIR 2 menghasilkan nilai 94,43\%, sedangkan PC4_NIR1 menghasilkan nilai overall accuracy $63,12 \%$.

\section{Perhitungan Kerapatan Vegetasi}

Proses perhitungan kerapatan vegetasi melibatkan NIR1_Merah dan NIR2_Merah. Proses pencarian nilai threshold melalui tahapan berulang kali yang disesuiakan dengan prosedur sampai mendapatkan nilai optimal. Proses binary dilakukan setelah mendapatkan nilai threshold yang diinginkan untuk membedakan vegetasi dan non vegetasi.
Perolehan nilai kerapatan vegetasi memperhitungkan sebaran vegetasi dan menggunakan metode yang sama dengan kepadatan bangunan. Unique identification digunakan untuk membuat grid $50 \mathrm{~m}$ dan $50 \mathrm{~m}$ dan menghasilkan 35 grid untuk analisis kerapatan vegetasi. Perhitungan akurasi diperoleh dari perbandingan perhitungan di laboratorium dengan ground truth sebanyak 180 sampel lapangan dengan metode stratified random sampling. Dari hasil tersebut diperoleh bahwa akurasi tertinggi diperoleh pada gabungan NIR1_Red dengan akurasi 99,51\% yang disertai producer accuracy vegetasi sebesar 99,15\% dan user accuracy 99,15\% (Tabel 3).

Tabel 3. Hasil Uji Akurasi Vegetasi

\begin{tabular}{lcclrr}
\hline Kombinasi & $\begin{array}{c}\text { Overall } \\
\text { Accuracy }\end{array}$ & $\begin{array}{c}\text { Keofisien } \\
\text { Kappa }\end{array}$ & Kelas & $\begin{array}{c}\text { Producer } \\
\text { Accuracy }\end{array}$ & User Accuracy \\
\hline \multirow{2}{*}{ NIR2_Red } & $92,87 \%$ & 0,8379 & Vegetasi & 99,15 & 80,69 \\
& & & Non Vegetasi & 90,31 & 99,62 \\
NIR1_Red & $99,51 \%$ & 0,9881 & Vegetasi & 99,15 & 99,15 \\
& & & Non Vegetasi & 99,65 & 99,65 \\
\hline
\end{tabular}


Nilai kerapatan vegetasi dihitung berdasarkan persentase tutupan vegetasi pada tiap grid yang dibentuk menggunakan UID sebesar $50 \mathrm{~m} \times 50 \mathrm{~m}$. NIR2_Red memperoleh luasan vegetasi tertinggi yaitu $59.114,88 \%$. Distribusi vegetasi sangat rapat terdapat pada kombinasi NIR2_Red dengan luas 55.481,92\% dan nilai ini overestimate jika dibandingkan dengan
NIR1_Red yang tidak mempunyai nilai vegetasi sangat rapat (Tabel 4). Distribusi paling tinggi ada pada vegetasi kerapatan rendah sesuai dengan distribusi di lapangan yang bervegasi rendah. Vegetasi kerapatan tinggi mempunyai luasan $5334,08 \mathrm{~m}^{2}$, kerapatan sedang $237,12 \mathrm{~m} 2$, dan kerapatan rendah sebesar 15.076,96 m².

Tabel 4. Kerapatan Vegetasi

\begin{tabular}{lcc}
\hline \multirow{2}{*}{ Kerapatan Vegetasi } & \multicolumn{2}{c}{ NIR 1 dan Red } \\
\cline { 2 - 3 } & Luas $\left(\mathrm{m}^{2}\right)$ & Persentase (\%) \\
\hline Sangat Tinggi & 0,00 & 0,00 \\
Tinggi & 5334,08 & 7,14 \\
Sedang & 237,12 & 0,32 \\
Rendah & 15076,96 & 20,19 \\
Tidak Bervegetasi & 0,00 & 0,00 \\
Luas & 20648,16 & 27,66 \\
\hline
\end{tabular}

\section{KESIMPULAN}

Penelitian ini melakukan uji coba dengan Citra Worldview-2 dengan berbagai karakteristik spectral yang ada. Citra worldview-2 mempunyai karakteristik yang beragam terkait dengan kenampakan fisik bentang lahan perkotaan. Walaupun SWIR band yang direkomendasikan untuk ekstraksi lahan terbangun tidak tersedia pada citra Worldview-2, sehingga pengembangan dan pendekatan menggunakan kombinasi berbagai band yang tersedia menjadi tujuan dalam penelitian ini. Hasil ekstraksi optimal untuk lahan terbangun menggunakan PCA menghasilkan kombinasi PC2_NIR1 dan PC2_NIR2 yang mempunyai akurasi 94,43\% serta kombinasi indeks ini menunjukkan luas yang sama untuk kepadatan bangunan. Lain halnya dengan ekstraksi vegetasi, saluran yang digunakan adalah NIR1_Red dan NIR2_Red yang masing-masing menunjukkan hasil optimal untuk ekstraksi vegetasi dengan overall accuracy $99,51 \%$ untuk NIR1_Red dan 92,87\% untuk NIR2_Red. Analisis berbasis grid terbukti sangat baik dalam perhitungan persentase kepadatan bangunan maupun kerapatan vegetasi dan hasilnya sangat akurat untuk mengukur luas areal bangunan dan vegetasi pada setiap grid.

\section{UCAPAN TERIMA KASIH}

Ucapan terima kasih disampaikan kepada Digital Globe Foundation yang telah memberikan citra Worldview-2. Beasiswa BPPDN yang telah memberikan dana untuk studi dan penelitian. Fakultas Geografi UGM atas segala bantuan dan dukungannya dalam menyelesaikan studi.

\section{DAFTAR PUSTAKA}

Abiden, M. Z. Z., Abidin, S. Z. Z., Jamaluddin, M. N. F., \& Mara, U. T. (2010). Pixel Based Urban Growth Model for Predicting Future Pattern. In 2010 6th International Colloqium on Signal Processing and its Applications (CSPA) (hal. 135-139).

Bahadur, R., \& Murayama, Y. (2012). Landscape and Urban Planning Scenario based urban growth allocation in Kathmandu Valley, Nepal. Landscape and Urban Planning, 105(1-2), 140-148. https:// doi.org/10.1016/j.landurbplan.2011.12.007

Blaschke, T. (2010). ISPRS Journal of Photogrammetry and Remote Sensing Object based image analysis for remote sensing. ISPRS Journal of Photogrammetry and Remote Sensing, 65(1), 2-16. https://doi.org/10.1016/j.isprsjprs.2009.06.004

Caroline, A. H., \& Hidayati, I. N. (2016). Pemanfaatan Citra Quickbird dan SIG untuk Pemetaan Tingkat Kenyamanan Permukiman di Kecamatan Semarang Barat dan Kecamatan Semarang Utara. Majalah Geografi Indonesia, 30(1), 1-8.

Chen, X. L., Zhao, H. M., Li, P. X., \& Yin, Z. Y. (2006). Remote sensing image-based analysis of the relationship between urban heat island and land use/cover changes. Remote Sensing of Environment, 104(2), 133-146. https://doi.org/10.1016/j. rse.2005.11.016

Deng, C., \& Wu, C. (2012). BCI: A biophysical composition index for remote sensing of urban environments. Remote Sensing of Environment, $127, \quad 247-259$. https://doi.org/10.1016/j. rse.2012.09.009 
Farizki, M., \& Anurogo, W. (2017). Pemetaan Kualitas Permukiman dengan Menggunakan Penginderaan Jauh dan SIG di Kecamatan Batam Kota, Batam. Majalah Geografi Indonesia, 31(1), 39-45.

Forestier, G., Puissant, A., Wemmert, C., \& Ganarski, P. (2012). Knowledge-based region labeling for remote sensing image interpretation. Computers, Environment and Urban Systems, 36(5), 470-480. https://doi.org/10.1016/j. compenvurbsys.2012.01.003

Guo, G., Wu, Z., Xiao, R., Chen, Y., Liu, X., \& Zhang, X. (2015). Impacts of urban biophysical composition on land surface temperature in urban heat island clusters. Landscape and Urban Planning, 135, 1-10. https://doi.org/10.1016/j. landurbplan.2014.11.007

Hidayati, I. N. (2010). Pemanfaatan Teori Bukti Demspter-Shaffer untuk Optimalisasi Penggunaan Lahan Berdasarkan Data Spasial dan Multi Sumber. Embryo, 7(1), 52-66.

Hidayati, I. N. (2013). Ekstraksi Data Indeks Vegetasi untuk Evaluasi Ruang Terbuka Hijau berdasarkan Citra ALOS di Kecamatan Ngaglik Kabupaten Sleman Yogyakarta. Agroteknologi, 3(2), 27-34.

Hidayati, I. N., Suharyadi, \& Danoedoro, P. (2017). Pemetaan Lahan Terbangun Perkotaan Menggunakan Pendekatan NDBI dan Segmentasi Semi-Automatik. In Prosiding Seminar Nasional Geografi UMS 2017 (hal. 19-28). Diambil dari https://publikasiilmiah.ums.ac.id/bitstream/ handle/11617/8998/semnasgeo2017_2. pdf? sequence $=1$

Johnson, B. (2014). Effects of Pansharpening on Vegetation Indices. ISPRS International Journal of Geo-Information, 3, 507-522. https://doi. org/10.3390/ijgi3020507

Kumar, A., Pandey, A. C., \& Jeyaseelan, A. T. (2012). Built-up and vegetation extraction and density mapping using WorldView-II. Geocarto Internat, 6049(May), 557-568. https://doi.org/10.1080/101 06049.2012.657695

Maithani, S. (2009). A Neural Network based Urban Growth Model of an Indian City. Journal Indian Social Remote Sensing, 2021(September), 363-376.

Millward-Hopkins, J. T., Tomlin, A. S., Ma, L., Ingham, D., \& Pourkashanian, M. (2011). Estimating Aerodynamic Parameters of Urban-Like Surfaces with Heterogeneous Building Heights. BoundaryLayer Meteorology, 141(3), 443-465. https://doi. org/10.1007/s10546-011-9640-2

Nichol, J., \& Wong, M. S. (2009). Mapping urban environmental quality using satellite data and multiple parameters. Environment and Planning B: Planning and Design, 36(1), 170-185. https:// doi.org/10.1068/b34034
Purwanto, A. (2015). Pemanfaatan Citra Landsat 8 Untuk Identifikasi Normalized Difference Vegetation Index ( Ndvi ) Di Kecamatan Silat Hilir Kabupaten Kapuas Hulu. Edukasi, 13(1), 27-36.

Richnau, G., Wiström, B., Nielsen, A. B., \& Löf, M. (2012). Creation of multi-layered canopystructures in young oak-dominated urban woodlands - The "ecological approach" revisited. Urban Forestry and Urban Greening, 11(2), 147-158. https://doi. org/10.1016/j.ufug.2011.12.005

Schindler, M., \& Caruso, G. (2014). Urban compactness and the trade-off between air pollution emission and exposure: Lessons from a spatially explicit theoretical model. Computers, Environment and Urban Systems, 45, 13-23. https://doi. org/10.1016/j.compenvurbsys.2014.01.004

Zha, Y., Gao, J., \& Ni, S. (2003). Use of normalized di ff erence built-up index in automatically mapping urban areas from TM imagery. International Journal of Remote Sensing, 24(3), 583-594. 